\title{
DIGITAL ECONOMY. THE CONVERSION OF THE TRADITIONAL ECONOMY AS A CONSEQUENCE OF THE ICT INNOVATIONS
}

\author{
Alexandra Ungureanu*, ORCID: 0000-0002-8538-5653 \\ Stefan cel Mare University of Suceava, 13 Universitatii St., 720229 Suceava, Romania \\ *alexandra.ungureanu2016@gmail.com
}

Received: 11. 30. 2020

Accepted: 01. 12. 2021

\begin{abstract}
The ability of the global economy to compete and evolve in the 21st century increasingly depends on the innovative and efficient use of information and communication technologies (ICT). Over the last decade, digitalization has improved decision-making in the global business ecosystem in a variety of contexts, and recent advances in technology transformed the business models in a way that reshapes the economic actor's interaction with business activities. The emergent conversion of the traditional economy is changing as automation tools, process standardization, and reuse of goods along with cloud computing technology shape the global economy towards digitalization, arising the concern to ensure the development of ICT proficiency in all sectors of the economy in order to create economic balance, avoiding a potential crisis based on the innovation deficit. The speed of digital transformation in the business environment will directly affect the models of economic growth and social development in the future. The present technological revolution is a valid indicator of the civilization progress of the 21st century and the digital transformation requires an improved association of organizational e-leadership skills, innovation, and business development based on business intelligence concepts. Therefore, the reduction of e-leadership skills can be a competitive disadvantage for the industry and a constraint on potential growth. From these considerations, the aim of the paper is to examine the diffusion of business intelligence elements in the global economy, providing examples of business models that have emerged as a result of digitalization improvement, and contributes to an overview of the main features of the digital economy that have emerged in these business models. Using a methodology based on the systematic review of the literature and global analysis regarding the topic, the paper presents a framework of the role that digitalization performs in the global economy transition from analog to digital configuration.
\end{abstract}

Keywords: innovation; progress; globalization, digital economy.

Rezumat. Capacitatea economiei globale de a concura și de a evolua în secolul 21 depinde din ce în ce mai mult de utilizarea inovatoare și eficientă a tehnologiilor informației și comunicațiilor (TIC). În ultimul deceniu, digitalizarea a îmbunătățit luarea deciziilor în ecosistemul global de afaceri într-o varietate de contexte, iar progresele recente în tehnologie au remodelat interacțiunea actorilor economici cu activitățile de afaceri. Conversia emergentă a economiei tradiționale se schimbă pe măsură ce instrumentele de automatizare, standardizarea proceselor și reutilizarea bunurilor împreună cu tehnologia cloud computing modelează economia globală spre digitalizare, apărând preocuparea de a asigura dezvoltarea competenței TIC în toate 
sectoarele economiei pentru a crea un echilibru economic, evitând o potențială criză bazată pe deficitul de inovare. Viteza transformării digitale în mediul de afaceri va afecta în mod direct modelele de creștere economică și dezvoltare socială în viitor. Revoluția tehnologică actuală este un indicator valid al progresului civilizației din secolul 21, iar transformarea digitală necesită o asociere îmbunătățită a abilităților organizaționale de e-leadership, inovație și dezvoltare a afacerilor bazate pe concepte de business intelligence. Prin urmare, reducerea abilităților de eleadership poate fi un dezavantaj competitiv pentru industrie și o constrângere asupra creșterii potențiale. Din aceste considerații, scopul lucrării este de a examina difuzarea elementelor de business intelligence în economia globală, oferind exemple de modele de afaceri care au apărut ca urmare a digitalizării și contribuie la o imagine de ansamblu a principalelor caracteristici ale sistemului digital, economie care a apărut în aceste modele de afaceri. Folosind o metodologie bazată pe revizuirea sistematică a literaturii și analiza globală a subiectului, lucrarea prezintă un cadru al rolului pe care îl are digitalizarea în tranziția economiei globale de la configurația analogică la cea digitală.

\section{Cuvinte cheie: inovație; progres; globalizare, economie digitală.}

\section{Introduction}

All sectors of the economy have adopted ICT to improve productivity, expand market coverage, and reduce operating costs. This adoption of ICT is illustrated by the spread of broadband connectivity in enterprises, which in almost all OECD countries is universal for large enterprises and reaches $90 \%$ or more, even in small enterprises [1].

The widespread adoption of ICT and the increase in the performance of these technologies has contributed to the development of new activities in both the public and private sectors. Together, these technologies have expanded market coverage and reduced costs, and enabled the development of new products and services, while also changing the way such products and services are produced and delivered, as well as the business models used by all companies, from multinational companies to start-ups.

The advent of the Internet has brought great changes, primarily to the entertainment, printing, advertising, and retail industries. In these sectors, the first major digital players initially started with traditional business models, adapting them to the best end-user technologies (both inside and outside organizations) and to wider interconnection on the Internet. In terms of technological advances and declining costs, ICT has proven to be a generic technology that has become an integral and central part of the business models of businesses operating throughout the economy.

Companies in all industries are now able to design and build business models around technological capabilities to improve flexibility and efficiency and expand their coverage in global markets [2]. These advances, together with the liberalization of trade policy and the reduction of transport costs, have expanded the capacity of enterprises in all sectors to take advantage of global value chains in which production processes can be geographically dispersed around the world and, at the same time, to exploit the characteristics of local markets. For example, in sectors that rely heavily on technology, research, and development, design and production can be managed centrally, while the group can be fragmented into different countries to exploit skilled labor and local resources [3]. Other sectors, such as retail trade, logistics, and education, financial services, production and agriculture, healthcare have changed and continue to change due to the spread of ICT.

With the adoption of digital technologies throughout the economy, the digital economy is becoming more and more the economy itself being impossible to separate the digital economy from the rest of the economy. Trying to isolate the digital economy as a separate sector 
inevitably requires arbitrary choices between what is digital and what is not. Therefore, the challenges and concerns raised by the digital economy can be better identified and addressed by analyzing existing structures adopted by actors in the global entrepreneurial ecosystem and new business models resulting from the application of business intelligence elements, focusing on the key features of the digital economy and determining which of these characteristics raises or exacerbates the challenges or concerns of the digital economy.

\section{E-commerce. The digital economy and the emergence of new business models}

The digital economy has given rise to a number of new business models. Although many of these models have parallels in traditional activities, modern advances in ICT have made it possible to carry out substantially more types of activities on a larger scale and over longer distances than was previously possible. Some of these business models can complement each other and, in some cases, overlap. Indeed, just as innovation in the digital economy allows the rapid development of new business models, it can quickly lead to the obsolescence of existing businesses.

Electronic commerce has been defined by the OECD regarding the indicators for the Information Society as "the sale or purchase of goods or services, carried out in a network by methods specially designed for the purpose of receiving or arranging orders. or services are ordered by these methods, but the payment and final delivery of the product or service are real. An e-commerce transaction can be between businesses, households, individuals, governments, and other public or private organizations" [4].

Business-to-business models - The vast majority of e-commerce consists of transactions in which one company sells products or services to another company (so-and-so B2B). This may include online versions of traditional transactions in which a wholesaler buys goods online, which are then sold to consumers at retail outlets.

Business to consumer models - B2C models were among the first forms of e-commerce. A company that follows a $\mathrm{B} 2 \mathrm{C}$ business model sells goods or services to people who operate outside the business. B2C models fall into several categories, including, for example, so-called "pure-play" online sellers without physical stores or off-network presence, click-and-mortar business integrates existing business with online sales, and manufacturers using the online business. to allow customers to order and customize the product directly [5].

Consumer to business models - This e-commerce model refers to individuals (consumers) who use the Internet to sell their products or services to companies and to look for sellers to bid for the products or services they need.

Models consumer-to-consumer - (C2C) operations are becoming increasingly common. $\mathrm{C} 2 \mathrm{C}$ e-commerce companies play the role of intermediaries, helping individual consumers to sell or rent, publishing their information on their website and facilitating transactions. These companies may or may not charge a consumer fee for these services, depending on their business model [6].

\section{The impact of e-business and cloud computing services on the global economy}

The Internet facilitates transactions in goods and services. This means that many transactions that would have taken place even without the Internet can be carried out more efficiently and at a lower cost. As a result, the number of companies trading on the Internet has increased dramatically in the last ten years [7].

E-business integration is the result of the usage of ICT strategies by enterprises with the aim of upgrading the entire business processes. The IT process that allows the electronic exchange of information between different elements of the business is known as applications for enterprise resource planning (ERP) And the process of integrating and managing the community 
with customers is performed using the customer relationship management (CRM) application [8].

According to statistics provided by Eurostat, at the European level, at least one in three companies use ERP software, and in 2018, this percentage reached $36 \%$. All these data show the fact that the use of the ERP application was lower in small companies in the SME sector, reaching a percentage of only $30 \%$, twice lower than the European percentage above the average which had a share of $60 \%$.

The adoption of ERP software applications was especially low for small businesses with a share of $30 \%$, which was twice less than the European average of $60 \%$ and more than two and a half times lower than the $80 \%$ registered by large companies.

Also in 2018, 33\% of enterprises in the European Union using CRM software to manage customer relations, while the share of small companies in the SME sector used applications in a percentage of $30 \%$, an aspect that offered a framework comparable to the use of ERP software.

At the same time, the use of CRM software in large enterprises has reached a usage threshold of $62 \%$, about 20 percent less with the implementation of ERP applications [10]. These statistics are presented in the figure 1.

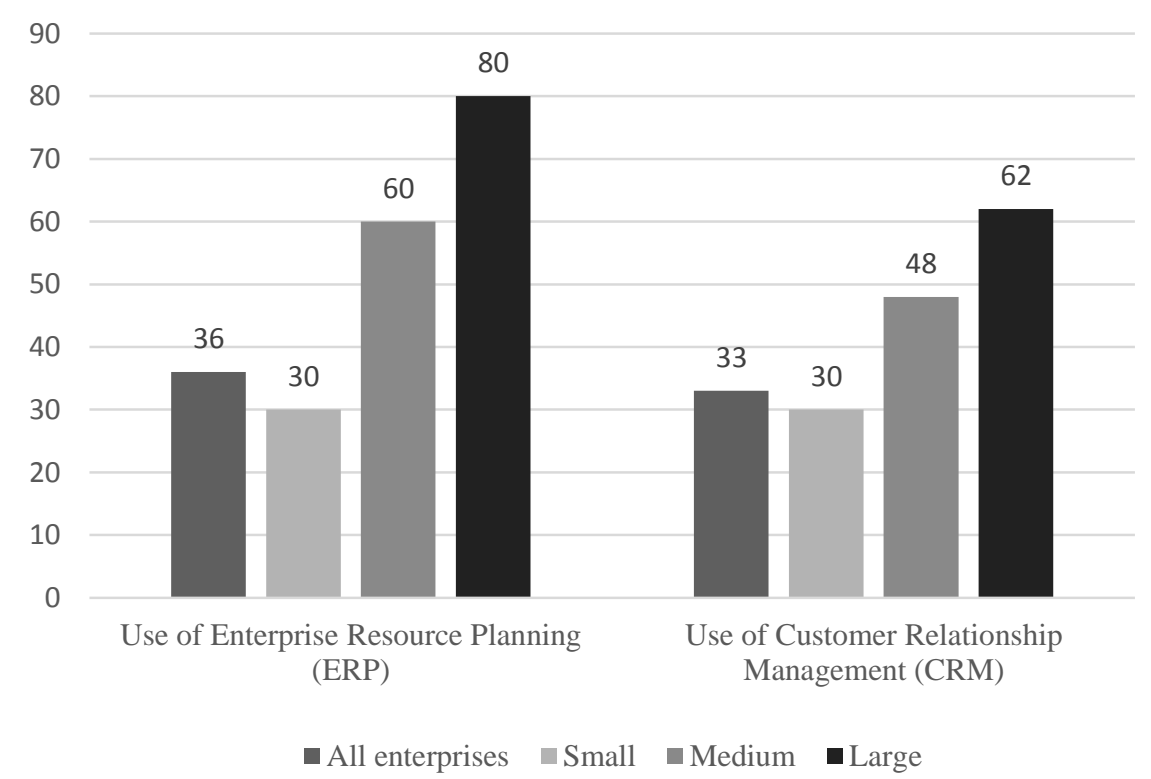

Figure 1. Adoption of e-business applications in enterprises by size class, EU-27, 2018

(\% enterprises).

Source: Digital economy and society statistics - enterprises Statistics Explained, Data extracted in September 2020 from Eurostat, (isoc_eb_iip), own processing.

\section{The main features of the digital economy}

There are a number of features that are increasingly relevant in the digital economy and that are potentially economically relevant [10]. While these characteristics may not all be present at the same time in a particular business, however, they increasingly characterize the modern economy.

These features include [11]:

Mobility of intangible assets - The development and exploitation of intangible assets is a fundamental feature of the digital economy. Investing in incorporating intangible assets contributes to creating value and growth for businesses in the digital economy. For example, digital companies often rely heavily on software and invest in research and development to upgrade existing software or develop new software products. 
Mobility of users and customers - Advances in ICT and the increasing connectivity that characterizes the digital economy translates into a large number of users being able to carry out distance activities across borders. The challenges of increasing consumer mobility are exacerbated by the ability of many consumers to use virtual personal networks or proxy servers that may, intentionally or unintentionally, mask the location of the final sale. The fact that many interactions on the Internet remain anonymous adds to the difficulty of identifying and locating users.

Mobility of company functions - Improvements in telecommunications, information management software, and personal computing have significantly reduced the cost of organizing and coordinating complex long-distance activities. Therefore, companies are always able to manage their global operations in an integrated way from a central location that can be geographically removed both from the location where the operations are carried out and from the location where suppliers or customers are offered. One impact of these changes has been the expansion of access capacity to remote markets, which has significantly increased the ability to provide goods and services across borders. This has been illustrated by the dramatic growth of international trade in recent years [12]. The data provided by Eurostat show that companies have used their own applications and websites rather than the marketplace, and the figure 2 shows the breakdown of sales channels that were chosen by companies for web sales for 2018 .

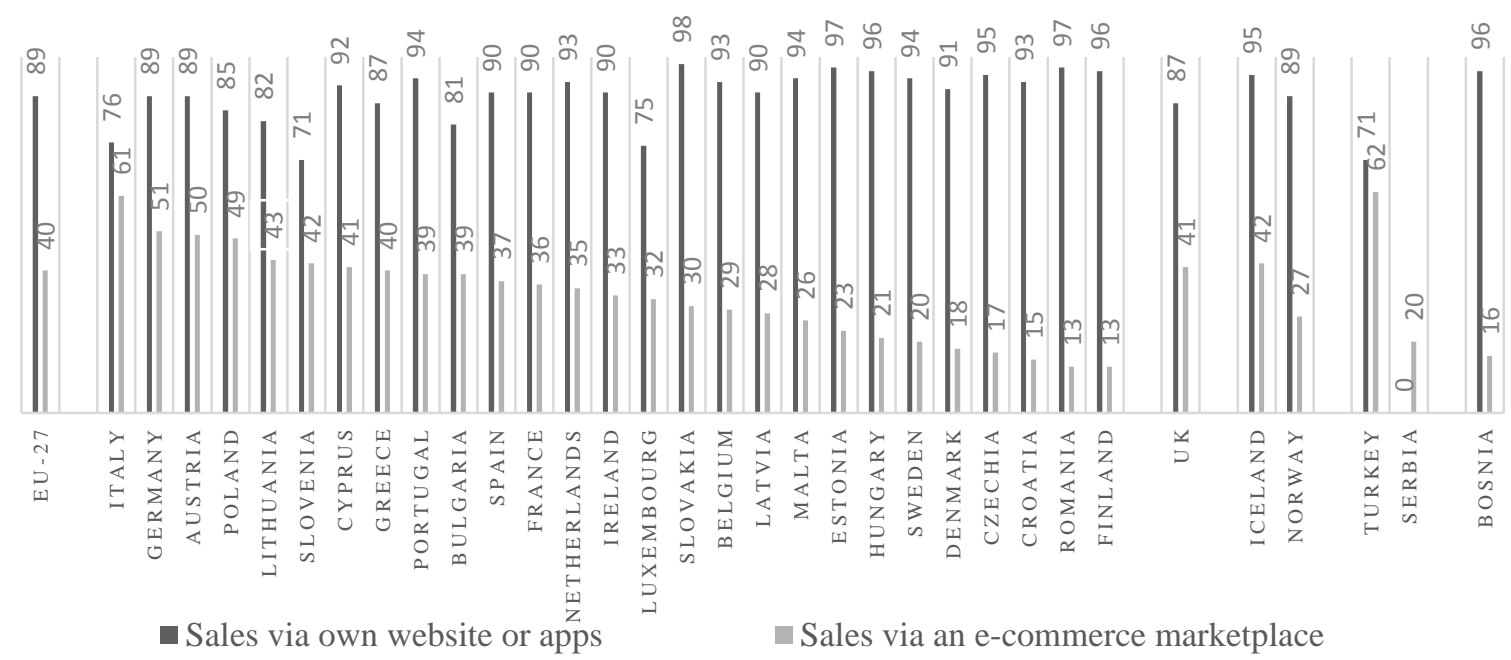

Figure 2. Enterprises with web sales, by type of sales, 2018 (\% of enterprises with web sales). Source: Digital economy and society statistics - enterprises Statistics Explained, Data extracted in September 2020 from Eurostat (isoc_eb_iip), own processing

The figure shows two segments: that of sales made through their own website and sales made via e-commerce marketplace, $89 \%$ of the companies of the 27 European states analyzed used their own websites or apps and a percentage of $40 \%$ used e-commerce marketplace [13]. The countries with the highest percentage of sales made via their own website or apps are Slovakia (98\%), Estonia (97\%), and Romania (97\%). Also in this segment, the countries with the lowest sales percentages are Slovenia (71\%), Luxembourg (75\%), and Italy (76\%).

Regarding the companies that chose the marketplace, the highest levels were reached by Italy (61\%), Germany (51\%), and Austria (50\%). The lowest percentages were recorded in Romania and Finland, as well as in Denmark (18\%), the Czech Republic (17\%), and Croatia (15\%).

In addition, technological advances allow companies to engage more and more in an economic activity that has the least need for staff. In many cases, companies are able to grow significantly in size, with minimal increases in the number of staff needed to manage the day-today operation of the activities (the so-called "massless ladder") [14]. This is especially true for internet activities, which in many cases have quickly accumulated a large number of users, while 
maintaining a small workforce. Therefore, the average income per employee of the top internet companies is substantially higher than other types of enterprises in the ICT sector. The ability to manage the business centrally, while maintaining considerable flexibility in the position of business functions, has increased the ability of companies to spread functions and activities between different countries.

Although this globalization of business among larger organizations is not a new phenomenon, the spread of the digital economy, combined with the growing importance of the "services" component, as well as reduced trade costs for trade and liberalization of investment and regulatory reforms, have helped eliminate logistical barriers and the increasing pace at which such globalization is possible. Technological advances have also allowed for greater integration of companies around the world, which has increased the flexibility of companies to spread their activities between different locations around the world, although these positions can be moved away from each other and physically. of their end customers. In addition to improving the flexibility of larger and more established organizations, advances in information and communication technology have also made it possible for small and medium-sized enterprises to reach global markets. In short, global interconnection has grown to unprecedented levels.

\section{Multilateral business models}

A multi-faceted model is one that is based on a market in which several distinct groups of people interact through an intermediary or platform, and the decisions of each group of people influence the outcome for other groups of people through positive negative externality. In a multi-faceted business model, the prices charged by the members of each group reflect the effects of these externalities. If the activities, on the one hand, create positive externality, on the other hand, the prices, can also be increased.

An example of a multi-sided business model that involves positive externalities for different parts of the market is a payment card system, which will be more valuable to merchants if more consumers use the card and more valuable to consumers if more merchants accept the card. Similarly, an operating system is more important to end users where more developers write software for it, and more valuable to software developers as more users of the operating system means more potential buyers of the software. Negative externality, on the one hand, and on the other can be offset by a lower or even free price for users. The growth of the digital economy has made multi-sided business models more widespread in a cross-border context. In this regard, there are two main features of multi-sided business models for the digital economy [15]:

Flexibility: The nature of digital information and internet infrastructure greatly expands the ability to design and implement multi-faceted business models. Resources such as content, user data, or executable code can be stored to create long-term value after they have been produced. This specificity of digital assets makes them a resource in business models where different sides of the market can be created dynamically and then adapted based on the evolution of technology, the latest expression of consumer demand and a company's position in the constantly evolving market. In addition, as will be discussed later, digital technology has improved the ability to collect, analyze and manipulate user and market data, which has allowed platforms to increase value for one part of the market share on the other side of the market.

Ability to extend: the digital economy also makes it easier to identify the different faces of the same business model in different countries. Considering that many traditional multi-sided business models such as advertising-subsidized broadcasting, or shopping malls that have been confined to a limited perimeter due to physical or regulatory constraints, top digital economy 
firms can more easily connect two parties that they are located away from each other to maximize value on each side.

For example, the resources intended to collect the data can be located near individual users, while the infrastructure needed to sell this data to paying customers can be located elsewhere.

The digital economy has two important categories of multi-sided business models. First, a company can implement several applications that provide complementary services. This creates two types of synergy: on the one hand, the various activities pool their resources such as executable code, content or user data; on the other hand, activities can be packaged in a package that is more attractive to users. Secondly, vertical platform models are used to make resources available to third-party developers to attract their creativity as part of open innovation strategies.

\section{Volatility}

Technological progress has led to advances in miniaturization and a downward trend in the cost of processing power. In addition, neither the end user nor, in many cases, the service provider is obliged to pay a marginal price for using the network. These factors, together with increased performance and capital expenditures, have significantly reduced barriers to entry for new internet-based businesses.

As a result, in a short period of time, companies that seemed to control a substantial part of the market and quickly enjoyed a dominant position found themselves losing market share to the challengers who built their business on more powerful technologies, on a more attractive proposition of pro value or on a more sustainable business model.

Due to the rapid pace of innovation, the few companies that have been successful in the long run have generally done so by investing significant resources in research and development and in acquiring start-ups with innovative ideas, by launching new features and new products. and by continuously evaluating and changing business models, in order to exploit its market position and maintain its dominant market position.

\section{Conclusions}

Technological advances have improved access to real-time market information and business analysis and improved communications within and between companies. These improvements have expanded the ability of companies to manage their global operations on an integrated basis, and improved telecommunications, information management software, and personal computers have significantly reduced the costs of organizing and coordinating complex tasks over long distances. new and more efficient business models. This integration has facilitated the adoption by companies of global business models that centralize functions at the regional or global level, rather than at the country level. Even for SMEs, it has now become possible for "micro-groups" to operate and have staff in different countries and continents.

The aim of the paper was to provide an overview of the impact on ICT innovations it has had on The Conversion of Traditional Economy, which seems to be becoming more challenging and common globally, alongside with the examination of business intelligence diffusion elements in the global economy, providing examples of business models that have emerged as a result of digitalization improvement, and contributes to an overview of the main features of the digital economy that have emerged in these business models. E-commerce, cloud computing and new business models are improvements and developments in technologies that, if combined with increased development and the experience of user organizations, can fundamentally change the way business intelligence as a result of ICT implications can lead to the development of the digital economy while offering a global balance of distribution. 
As operations around the world have become more integrated, production processes are increasingly integrated into global value chains, where different stages of production are distributed in several different countries and are carried out by a mix of independent and affiliated suppliers. Companies are increasingly able to choose the optimal location for production activities and fixed assets, although this position may be far from the position of customers or the location of other stages of production. In addition, rapid advances in information and communication technology have meant that services such as data entry, information processing, research, and counseling can always be carried out remotely. In addition, skills and talents remain an essential resource for the digital economy. While many features can be performed with limited staff, managers, developers, software architects, and designers, among other key functions, remain critical. Therefore, the position of many of the substantial functions of a digital business needs to take place in places where these key people are willing to work. In addition, while digital services can significantly expand business-coverage, the same services often require massive investment in infrastructure components. For these reasons, I believe that there are good reasons for companies to be positioned as close as possible to the key markets of internet users so that the user experience is less latent, faster, and of higher quality. In addition, in some companies, the need for a tangible presence in a jurisdiction for regulatory reasons may also limit the options for locating infrastructure and business activities.

\section{References}

1. OECD (2014), The Digital Economy, New Business Models and Key Features: Addressing the Tax Challenges of the Digital Economy, OECD Publishing, (2014), pg. 78-85. Available from: https://www.oecdilibrary.org/docserver/9789264218789-7 en.pdf?expires=1606671656\&id=id\&accname=guest\&checksum=9 6790BC04F1ACBA2677541

2. Teece J. D., Business Models, Business Strategy and Innovation, Long Range Planning, Volume 43, Issues 2-3, pg. 172-194, ISSN 0024-6301, (2010). Available from: https://doi.org/10.1016/j.Irp.2009.07.003

3. Schultz Mark M., Gelder A., Creative Development: Helping Poor Countries by Building Creative Industries, 2005 Convention Capacity-Building Programme, pg. 22-28. $\quad$ (2012). Available from:https://en.unesco.org/creativity/sites/creativity/files/digitallibrary/Creative\%20Development_Building\%20Creative\%20Industries.pdf

4. Measuring The Information Economy 2002, Annex 4. The Oecd Definitions Of Internet And E-Commerce Transactions, pg. 89. Available from: http://www.oecd.org/digital/ieconomy/2771174.pdf

5. Reynolds J. E-commerce: A critical review, International Journal of Retail \& Distribution Management 28(10):417444, DOI: 10.1108/09590550010349253, (2000). Available from: https://www.researchgate.net/ publication/247629187_E-commerce_A_critical_review

6. Consumer-to-consumer (C2C) e-commerce: Definition, business model \& examples. Available from: https://www.statista.com/markets/413/topic/983/c2c-e-commerce/

7. Lee H., Clark T. Impacts of the Electronic Marketplace on Transaction Cost and Market Structure. International Journal of Electronic Commerce, 1(1), pg. 127-149, (2020). Available from: from http://www.jstor.org/stable/27750803

8. Nader M., Alomar Z.S., The Role of Enterprise Resource Planning Systems ERP in Improving Customer Relationship Management CRM: An Empirical Study of Safeway Company of Jordan, International Journal of Business and Management; Vol. 13, No. 8, ISSN 1833-3850, Published by Canadian Center of Science and Education, (2018). Available from: https://www.researchgate.net/publication/327821610_The_ Role_of_Enterprise_Resource_Planning_Systems_ERP_in_Improving_Customer_Relationship_Management_CR M_An_Empirical_Study_of_Safeway_Company_of_Jordan

9. Eurostat Statistics Explained, E-Commerce Statistics, Data extracted in December 2019. Planned article update: February 2021. Available from: https://ec.europa.eu/eurostat/statistics-explained/pdfscache/14386.pdf

10. Szczepański M., EPRS | Is data the new oil? Competition issues in the digital economy, European Union 2020, pg. 1-8, (2020). Available from: https://www.europarl.europa.eu/RegData/etudes/BRIE/2020/646117/ EPRS_BRI(2020)646117_EN.pdf

11. Digital Economy Report 2019 - Value Creation And Capture: Implications For Developing Countries, UNCTAD United Nations Conference On Trade And Development Digital Economy, United Nations Publications, pg. 108119, ISBN 978-92-1-112955-7, (2019). Available from: https://unctad.org/system/files/ officialdocument/der2019_en.pdf 
12. European Economic Forecast Institutional Paper 125 | May 2020, Luxembourg: Publications Office of the European Union, pg. 79 - 85, ISBN 978-92-76-16314-5, DOI:10.2765/788367, (2020). Available from: https://ec.europa.eu/info/sites/info/files/economy-finance/ip125_en.pdf

13. Eurostat Statistics Explained, Digital Economy and Society Statistics - Enterprises, Data extracted in September 2020, Planned article update: September 2021, pg. 1-23, ISSN 24438219. Available from: https://ec.europa.eu/eurostat/statistics-explained/index.php/Digital_economy_and_society_statistics__enterprises

14. OECD 2014 - The Impacts Of Large Research Infrastructures on Economic Innovation and on Society: Case Studies at CERN, pg. 55-64, (2014). Available from: http://www.oecd.org/sti/inno/CERN-case-studies.pdf

15. Yablonsky S., Multi-Sided Platforms (MSPs) and Sharing Strategies in the Digital Economy: Emerging Research and Opportunities, IGI Global, ISBN10: 1522554572, pg. 11-18, (2018). Available from: https://www.igiglobal.com/gateway/chapter/201260 